\title{
The effectiveness of protected areas and indigenous lands in representing threatened plant species in Brazil
}

\author{
Bruno R. Ribeiro ${ }^{1,2,3,4}$, Eline Martins ${ }^{3}$, Gustavo Martinelli $^{3}$ \& Rafael Loyola ${ }^{1,3}$
}

\begin{abstract}
Brazil is signatory of the Global Strategy for Plant Conservation (GSPC), which provides guidelines and directions to existing national policies. This strategy aims to halt the continuing loss of plant diversity through the achievement of 16 outcome-based targets set for 2020 . One of these targets (target 7) states that at least $75 \%$ of known threatened plant species should be preserved in situ. Here, we assessed the effectiveness of the Brazilian current network of protected areas (PAs) and indigenous lands (ILs) in representing all known threatened plant species. We found that the number of species represented inside PAs and ILs varied according to data type. When using occurrence records, we found that $699(33 \%)$ threatened plant species lie completely outside PAs (and/or ILs) and that 1,405 species (67\%) have at least one record inside at least one PA (and/or IL). The number of species unrepresented decreased when we considered polygons of distribution. In this case, only $219(10 \%)$ are supposedly unprotected. Although Brazil is almost reaching GSPC Target 7 in terms of absolute numbers, the government still needs to allocate resources for properly managing and improving the conservation status of its imperiled flora and expand the network of PAs.
\end{abstract}

Key words: Aichi Targets, conservation policy, gap analysis, GSPC, knowing-doing gap.

\section{Resumo}

O Brasil é signatário da Estratégia Global para Conservação de Plantas (GSPC), que fornece diretrizes e orientações para políticas públicas nacionais já existentes. Esta estratégia visa frear a perda contínua da diversidade de plantas por meio da implementação de 16 metas baseadas em resultados estabelecidas para 2020. Segundo uma dessas metas (meta 7), $75 \%$ das espécies de plantas ameaçadas conhecidas até então devem ser preservadas in situ. Aqui, avaliamos a eficiência da atual rede brasileira de unidades de conservação (UCs) e terras indígenas (TIs) em representar todas espécies de plantas ameaçadas. Descobrimos que o número de espécies presentes em UCs e TIs depende do tipo de dado utilizado. Ao utilizar registros de ocorrência, descobrimos que 699 (33\%) espécies ameaçadas de plantas encontram-se completamente fora dessas áreas, e que 1.405 espécies (67\%) possuem pelo menos um registro dentro de pelo menos uma UC ou TI O número de espécies não representadas diminiuiu quando consideramos polígonos de distribuição de espécies. Neste caso, apenas $219(10 \%)$ das espécies encontram-se supostamente desprotegidas. Embora o Brasil esteja alcançando a meta 7 da GSPC em números absolutos, o governo ainda precisa alocar recursos para manejar de forma adequada e melhorar o estado de conservação de sua flora ameaçada e para epansão a rede de UCs.

Palavras-chave: Metas de Aichi, políticas públicas para conservação, análise de lacunas, GSPC, lacuna conhecimento-implementação.

\section{Introduction}

Plants are the backbone of life on Earth and are a source of food, timber, medicine, and a wide range of goods and services such as pure water, erosion control, and climate regulation; which are essential for human wellbeing (Kier et al. 2005; Corlett 2016). Nevertheless, flora conservation is still a big challenge to be faced in megadiverse countries.

Brazil, for example, harbors the richest flora on the planet, with at least 33,100 native terrestrial

\footnotetext{
${ }^{1}$ Universidade Federal de Goiás, Depto. Ecologia, Lab. Biogeografia da Conservação, Av. Esperança s/n, Campus Samambaia, 74690-900, Goiânia, GO, Brazil.

${ }^{2}$ Universidade Federal de Goiás, Prog. Pós-graduação em Ecologia e Evolução, Av. Esperança s/n, Campus Samambaia, 74690-900, Goiânia, GO, Brazil.

${ }^{3}$ Instituto de Pesquisas Jardim Botânico do Rio de Janeiro, Centro Nacional de Conservação da Flora, R. Pacheco Leão 915, 22460-030, Rio de Janeiro, RJ, Brazil.

${ }^{4}$ Author for correspondence: ribeiro.brr@gmail.com
} 
species described, being 53\% endemics (BFG 2015; Flora do Brasil 2020 2017). This enormous biodiversity, however, is threatened by habitat loss and fragmentation, mining activities, infrastructure development, overexploitation of species of economic interest, invasive species, and climate change (Martinelli \& Moraes 2013). As a consequence, 2,113 plant species now figure in the Brazilian official and most up-to-date list of threatened species (MMA 2014). Furthermore, much more species are supposed to be threatened, as just $17 \%$ of the Brazilian flora has been formally assessed so far by the National Centre for Flora Conservation (Martinelli \& Moraes 2013; Martinelli et al. 2014, 2018).

As signatory of the Convention on Biological Diversity (CBD), Brazil has committed to protect $75 \%$ of its known threatened plant species inside the country's PAs. This goal relates to target 7 of the Global Strategy for Plant Conservation (GSPC), a program agreed at the CBD meeting in Nagoya in 2010 (Convention on Biological Diversity 2016a). The GSPC aims to halt the continuing loss of plant diversity through the achievement of 16 outcome-based targets set for 2020 (Convention on Biological Diversity 2016a). So far, few countries have already assessed their progress towards Target 7 . For example, 66\% of South Africa and 44\% of Spain threatened plant species have at least one population occurring in PAs (Convention on Biological Diversity 2016b; Muñoz-Rodríguez et al. 2016).

Among several conservation strategies designed to avoid species extinction, protecting species in their natural habitats is the simplest, cheapest and most effective one (Loucks et al. 2008). Brazil has one of the largest PAs system in the world (MMA 2018; Pacheco et al. 2018). However, even with the expansion of its network of PAs in the last decades, PAs are not homogeneously distributed among Brazilian biomes (Pacheco et al. 2018). Further, information on species representation inside (or outside) PAs is barely available (but see Ferreira \& Valdujo 2014; Oliveira et al. 2017).

Here, we assessed the effectiveness of the Brazilian current network of PAs in representing all known threatened plant species. We did a comprehensive gap analysis considering different types of species distribution data (occurrence records and polygons) to evaluate how close Brazil is to achieve GSPC's target 7.

\section{Methods}

Species and protected area data

Species records were compiled by CNCFlora (Centro Nacional de Conservação da Flora, National Center of Flora Conservation) using the following procedure: data on species records were retrieved from the Global Biodiversity Information Facility (<https://www.gbif.org $>$ ), SpeciesLink ( $<$ http://splink.cria.org.br $>$ ), Rio de Janeiro Botanic Garden herbarium ( $<$ http://jabot. jbrj.gov.br $>$ ), and botanic experts' databases. These data were cleaned and records without explicit geographic information were spatially projected using information from the herbaria vouchers, whenever possible.

Species distribution polygons were built by the CNCFlora using ArcGIS v1.0 (ESRI) following the precision of species occurrence records. All records had a geographic precision associated to nine classes: a) 0 to $250 \mathrm{~m}$; b) 250 to $1,000 \mathrm{~m}$; c) 1 to $5 \mathrm{~km}$; d) 5 to $10 \mathrm{~km}$; e) 10 to $50 \mathrm{~km}$; f) 50 to $100 \mathrm{~km}$; g) centroid of polygon; h) centroid of protected area; i) centroid of the municipality. The CNCFlora defines the likely distribution of a given species as the sum of area covered by these polygons (for details see also Martinelli \& Moraes 2013 and Loyola et al. 2014a).

We obtained species distribution as both occurrence records and polygons for 2104 species listed in the Red Book of Brazilian Flora (Martinelli \& Moraes 2013) from CNCFlora. CNCFlora is the Red List authority in Brazil (Martins et al. 2017) and this is the most complete and up-to-date dataset of Brazilian threatened flora distribution available. We obtained data on PAs and indigenous lands (ILs) from a range of sources (Tab. 1). We considered all classes of PAs, i.e., federal, state and municipal, which include full protection and sustainable use PAs (IUCN categories I-III and IV-VII, respectively) and also the ILs (MMA 2016). Although not included in the Brazilian law that establishes the roles and categories of PAs (MMA 2000), ILs are natural areas that encompass nearly $13 \%$ of the Brazilian territory (Pacheco et al. 2018), playing a key role in preventing deforestation (Soares-Filho et al. 2010). We did not include in the analysis Permanent Preservation Areas (e.g., riverside and hilltops forest buffers) and Legal Reserves (i.e., part of private lands that must be set aside for conservation) because no spatial information on these areas was readily available. 
Table 1 - Source of data used in this study.

\begin{tabular}{ll}
\hline Data & Source \\
\hline $\begin{array}{l}\text { Species distribution data } \\
\text { (records and polygons) }\end{array}$ & $\begin{array}{l}\text { National Centre for Flora Conservation } \\
(<\mathrm{http} / / / \text { www.cncflora.jbrj.gov.br }>)\end{array}$ \\
$\begin{array}{l}\text { Shapefile of Protected Areas } \\
\text { (full protection and sustainable use) }\end{array}$ & $\begin{array}{l}\text { Brazilian Ministry of the Environment } \\
(<\mathrm{http}: / / \text { mapas.mma.gov.br/i3geo/datadownload.htm }>)\end{array}$ \\
Shapefile of Indigenous Lands & $\begin{array}{l}\text { National Indian Foundation } \\
(<\mathrm{http}: / / \text { www.funai.gov.br/index.php/shape }>)\end{array}$ \\
Shapefile of Brazilian biomes & $\begin{array}{l}\text { Brazilian Ministry of the Environment } \\
(<\mathrm{http}: / / \text { mapas.mma.gov.br/i3geo/datadownload.htm }>)\end{array}$ \\
\hline
\end{tabular}

To evaluate the effectiveness of PAs in representing the threatened flora we superimpose species distribution data onto a map of Brazilian PAs. In the analysis, we considered a species as "represented" in a given PA if at least one record or any extent of its distribution polygon overlapped any PA; otherwise the species was considered a "gap species". We used function over (package "sp"; Pebesma \& Bivand 2005) to overlap species records and PAs. To overlap species polygons and PAs, we created a grid of $2 \mathrm{~km}$ of resolution at the extent of each species polygon. Then, we use this grid to rasterizing species polygons and PAs which lied inside species polygons. All data sources and the $\mathrm{R}$ script used to run the analysis are available in the Appendix $1(<\mathrm{https}$ ://doi.org/10.6084/ m9.figshare.7221971.v1>).

\section{Results}

Most records of threatened plant species were concentrated in the Atlantic rainforest and Caatinga biomes, whereas large areas in the Amazon remain poorly sampled or not sampled at all (Fig. 1). On the one hand, the Atlantic rainforest harbored the highest number of threatened plant species in Brazil $(\mathrm{n}=1,507)$ although only $\sim 11 \%$ of its extent is covered by PAs and ILs (Pacheco et al. 2018). On the other hand, the Brazilian Amazon had the largest coverage of PAs and ILs in Brazil ( $\sim 53 \%$ of biome extent), but has only 85 threatened species (Fig. 1).

We found that the number of species occurring inside and outside PAs varied according to the type of distribution data used to do the analysis. When we used occurrence records, 699 species (33\%) fell completely outside PAs or ILs (Fig. 2a). A total of 1,405 species $(67 \%)$ had at least one record inside PAs and ILs; and $82 \%$ had up to 10 records inside PAs and ILs [Fig. 3; Tab. S1 (<https://doi. org/10.6084/m9.figshare.7221971.v1>)].

When running the analysis with distribution polygons, we found that the number of gap species inside PAs or ILs reduced to 219 species $(10 \%$; Fig. 2b). Species fully covered (i.e., 100\% of their distribution) by Brazilian PAs and ILs added to 29 species (1.3\%); and 807 species (38\%) had up to $20 \%$ of their range represented in these areas [Fig. 2b; Tab. S1 (<https://doi.org/10.6084/ m9.figshare.7221971.v1>)].

Species representation also varied between PAs and ILs. We found 81 (4\%) threatened species occurring in ILs, 14 of them only occurred in these areas. In PAs, the number of species represented varied according to PA category: $c a$. $39 \%$ of species were found only inside full protection PAs, whereas $34 \%$ of species only occurred in sustainable use PAs, being one-third represented by Environmental Protection Areas, a category of PA in which a range of economic activities is allowed. Further, nearly $76 \%$ of species were found exclusively in terrestrial PAs and only $9 \%$ occurred in marine and coastal PAs; $15 \%$ of species were found in both.

On average, $55 \%$ of threatened species with at least one record inside PAs or ILs are currently listed as endangered (EN), 23\% as vulnerable (VU), and $22 \%$ as critically endangered (CR) species. For gap species (i.e., those not represented in PAs or ILs), on average, $51 \%, 26 \%$ and $23 \%$ are EN, VU and CR, respectively (Fig. 2).

\section{Discussion}

How far is Brazil from achieving GSPC Target 7? Being pragmatic, we would state that Brazil is quite close to fulfilling its commitment, given that $67 \%$ of threatened flora is represented inside any given PA or IL. This figure is even higher 
when we analyzed data on species distribution (i.e., polygons), in which $90 \%$ of species occur in PAs or ILs. These results represent a great accomplishment for plant conservation in Brazil and we are optimistic that this target will be eventually achieved.

However, our results should be interpreted with caution given that the distribution of species records is heavily skewed towards the northeast and southeast Brazil (i.e., Atlantic Forest and Caatinga biomes), as also observed by Schulman et al. (2007), Sousa-Baena et al. (2014), and Oliveira et al. (2017). Further, the occurrence of a species in a given PA or IL offers no guarantee to species' effective long-term conservation. Following the CBD (Convention on Biological Diversity 2016b), to be effective, in situ conservation must ensure viable populations of species in at least one PA. Therefore, a metric such as species' occurrence inside PAs could not be enough to ensure the conservation of threatened plant species given that $82 \%$ of them are represented in PAs by less

- Records in Protected Areas (PA)

- Records in Indigenous Lands

- Records outside PA

Indigenous Lands

PA - Full Protection

PA - Sustainable Use

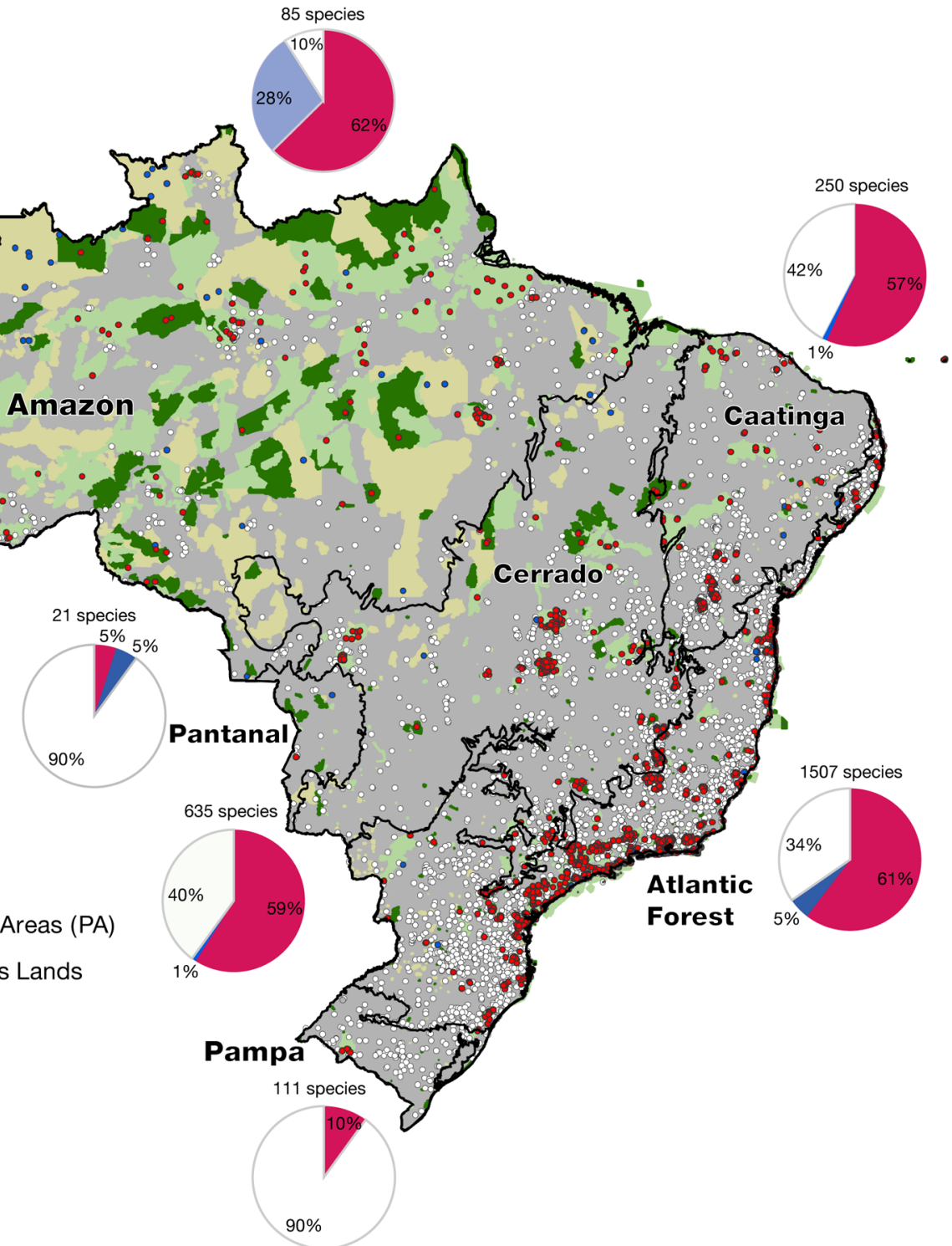

Figure 1 - Distribution of Brazilian threatened plant species' records inside and outside protected areas (PAs) regarded as full protection, sustainable use PAs, and indigenous lands (ILs). The number and proportion of species representation inside each PA category and ILs are shown in the pie charts. 
than 10 records. Further, commission errors (i.e., considering a species present in a given PA where it is absent) are also an inevitable consequence of using species polygon and can result in an overestimation of the representatives of species in PAs. Being aware of our current knowledge is a first step for supporting decision making regarding biodiversity conservation. There is a need to foster biodiversity inventories particularly in poorly sampled PAs (Sobral \& Stehmann 2009; Martins et al. 2017; Loyola et al. 2018). To address this issue, more investments in PAs infrastructure, new surveys and inventories, trained personnel, management plans, institutional capacity, and public engagement are urgently needed. Opening ILs to scientific expeditions is also paramount (Coelho et al. 2015).

We should also note that searching for an increase in the number of threatened species inside PAs or ILs might be the wrong focus (Heywood 2017); this number must actually reduce. The ultimate aim of GSPC is to halt the current and continuous loss of plant diversity by reducing species extinction risk and consequently reducing the number of threatened species (Heywood 2017). In situ conservation is indeed the first step required to avoiding habitat loss and to restore
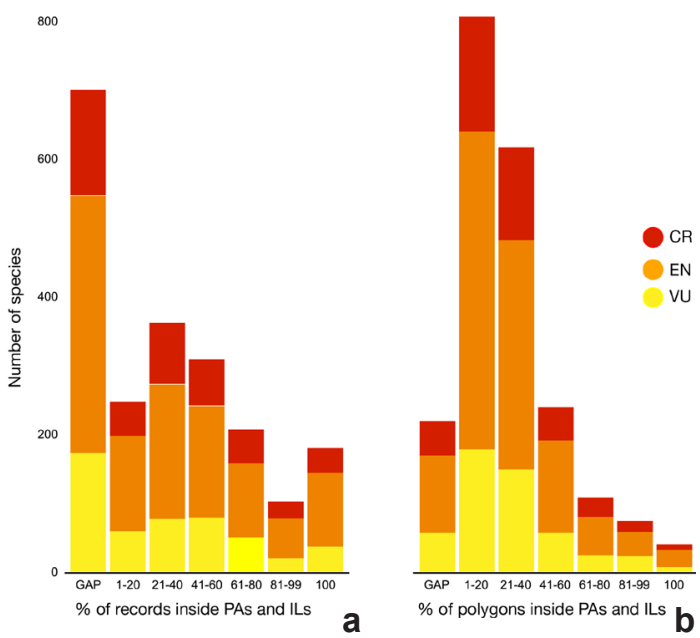

Figure $2-a-b$. Number of threatened plant species and their representation in the Brazilian network of protected areas and indigenous lands according to species' threat category and type of distribution data - a. species' records; b. distribution polygons. Species totally outside protected areas are shown as GAP. CR $=$ Critically Endangered); EN = Endangered; and VU $=$ Vulnerable. or sustain native plant populations (Convention on Biological Diversity 2016a; Heywood 2017). However, even inside PAs threats such as biological invasion (Nori et al. 2011; Loyola et al. 2012) habitat loss (Hansen et al. 2013), climate change (Lemes et al. 2013; Loyola et al. 2014b; Ferro et al. 2014), overexploitation (Castilho et al. 2017) still take place; and the very PAs could suffer from downgrading, downsizing and degazettement (Bernard et al. 2014; Oliver et al. 2016; Heywood 2017; Martins et al. 2017). Therefore, looking representation of threatened species inside PAs or ILs is not the big question; instead we should looking for how to guarantee the survival of these species once they are found inside these areas (Pressey et al. 2015).

We found that $33 \%$ of species records or $10 \%$ of species distribution polygons are fully outside any given PA or IL. Gap species are the most in need of conservation actions owing to fast habitat loss, mainly in the Brazilian Cerrado, the most vulnerable savanna worldwide (Strassburg et al. 2017; Vieira et al. 2018). Conservation of gap species demands area-based conservation measures undertaken outside of and complementary to PAs (Heywood 2017) and ILs. For instance, the Brazilian Forest Code, if appropriately enforced, may offer a great opportunity for plant conservation in private properties since it requires that part of

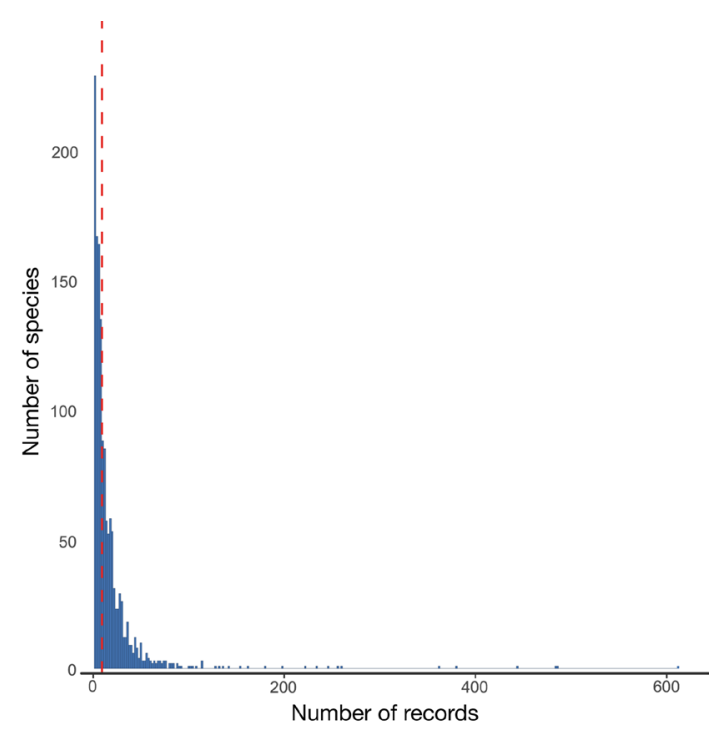

Figure 3 - Number of records of species inside protected areas (PAs) and indigenous lands (ILs). The red dashed line indicates that $82 \%$ species has less than 10 records inside PAs or ILs. 
private area - ranging from $80 \%$ in the Amazon and $20 \%$ other regions of Brazil - should be set aside for conservation or restoration (Brancalion et al. 2016). Furthermore, priority areas for plant conservation have already been defined at the national (Loyola et al. 2014a) and regional (Loyola \& Machado 2015a; Loyola et al. 2015b, 2018) scale.

Beyond in situ conservation, Brazil and other countries also rely on species recovery plans as another tool for species conservation. These plans encompass habitat management and/or restoration, ex situ conservation, development of educational and outreach programs, environmental policy development, and continuing monitoring (Convention on Biological Diversity 2016a; Heywood 2017). To date, 873 threatened plant species are included in species recovery plans in Brazil (Martins et al. 2014; Pougy et al. 2015a,b, 2018). Surely, the main obstacles for improving species' threat status through the implementation of strategies set out in recovery plans are the inadequate funding for conservation and science in general. This situation is exacerbated by the interaction of inadequate funding with poor governance, internal corruption, lack of political will and the current political instability (Loyola 2014; Fearnside 2016; Fernandes et al. 2017).

Despite the encouraging progress made by some countries in pursuing GSPC Target 7, global progress remains difficult to be assessed because of slow progress with Target 2 (assessment of species conservation status; see Martins et al., this issue; Bachman et al. 2017) and the lack of distribution data for threatened species (Convention on Biological Diversity 2016b). The crucial importance of a global assessment is highlighted by the high number of species supposed to be threatened. An estimate made using nearly $16 \%$ of plants of the world showed that $43 \%$ of these plants are categorized as threatened with extinction (Sharrock et al. 2014).

Our quantitative analysis sheds light on the status quo of Brazilian responsibility and commitment regarding GSPC target 7 . Great advances in plant conservation in Brazil have been achieved in the last decades (see Martinelli \& Moraes 2013; Loyola et al. 2014a; BFG 2015; Martins et al. 2017; MMA 2018). We conclude that although Brazil is almost reaching GSPC Target 7 in terms of absolute numbers, the government still needs to allocate resources for properly managing and improving the conservation status of its imperiled flora.

\section{Acknowledgements}

BRR thanks the CAPES for providing a $\mathrm{PhD}$ fellowship; RL research is funded by CNPq (grant 308532/2014-7); O Boticário Group Foundation for Nature Protection (grant PROG_0008_2013), and CNCFlora (grant 065/2016). This paper is a contribution of the INCT in Ecology, Evolution and Biodiversity Conservation founded by MCTIC/ CNPq/FAPEG (grant 465610/2014-5).

\section{References}

Bachman SP, Nic Lughadha EM \& Rivers MC (2017) Quantifying progress toward a conservation assessment for all plants. Conservation Biology 0: 1-9.

Bernard E, Penna LAO \& Araújo E (2014) Downgrading, downsizing, degazettement, and reclassification of protected areas in Brazil. Conservation Biology 28: 939-950.

BFG - The Brazil Flora Group (2015) Growing knowledge: an overview of seed plant diversity in Brazil. Rodriguésia 66: 1085-1113.

Brancalion PHS, Garcia LC, Loyola R, Rodrigues RR, Pillar VD \& Lewinsohn TM (2016) A critical analysis of the Native Vegetation Protection Law of Brazil (2012): updates and ongoing initiatives. Natureza \& Conservação 14: 1-15.

Castilho LC, De Vleeschouwer KM, Milner-Gulland EJ \& Schiavetti A(2017) Hunting of mammal species in protected areas of the southern Bahian Atlantic Forest, Brazil. Oryx : 1-11.

Coelho MAN, Costa DP, Martinelli G, Moraes MÁ, Forzza RC \& Azoury R (2015) Expedições às montanhas da Amazônia. Andrea Jakobsson Estúdio, Rio de Janeiro. 244p.

Convention on Biological Diversity (2016a) Global strategy for plant conservation: introduction. Available at $<$ https://www.cbd.int/gspc/intro.shtml $>$. Access on December 9, 2017.

Convention on Biological Diversity (2016b) Progress in implementation of the targets of the global strategy for plant conservation. Available at $<$ https://www.cbd. int/doc/meetings/sbi/sbi-01/information/sbi-01-inf32-en.pdf $>$. Access on 09 December 2017.

Corlett RT (2016) Plant diversity in a changing world: status, trends, and conservation needs. Plant Diversity 38: $10-16$.

Fearnside PM (2016) Brazilian politics threaten environmental policies. Science 353: 746-748.

Fernandes GW, Vale MM, Overbeck GE, Bustamante MMC, Grelle CEV, Bergallo HG \& Pillar VD (2017) Dismantling Brazil's science threatens global biodiversity heritage. Perspectives in Ecology and Conservation 15: 239-243.

Ferreira MN \& Valdujo PH (2014) Observatório de UCs: biodiversidade em unidades de conservação. WWFBrasil, Brasília. 64p. 
Ferro VG, Lemes P, Melo AS \& Loyola R (2014) The reduced effectiveness of protected areas under climate change threatens atlantic forest tiger moths. PLoS ONE 9: e107792.

Flora do Brasil 2020 (2017, em construção) Jardim Botânico do Rio de Janeiro. Available at $<$ http:// floradobrasil.jbrj.gov.br/>. Access on 09 December 2017.

Hansen MC, Potapov PV, Moore R, Hancher M, Turubanova SA, Tyukavina A \& Townshend JRG (2013) High-resolution global maps of $21^{\text {st }}$-century forest cover change. Science 342: 850-853.

Heywood VH (2017) Plant conservation in the Anthropocene - Challenges and future prospects. Plant Diversity 39: 314-330.

Kier G, Mutke J, Dinerstein E, Ricketts TH, Küper W, Kreft H \& Barthlott W (2005) Global patterns of plant diversity and floristic knowledge. Journal of Biogeography 32: 1107-1116.

Lemes P, Melo AS \& Loyola RD (2013) Climate change threatens protected areas of the Atlantic Forest. Biodiversity and Conservation 23: 357-368.

Loucks C, Ricketts TH, Naidoo R, Lamoreux J \& Hoekstra J (2008) Explaining the global pattern of protected area coverage: relative importance of vertebrate biodiversity, human activities and agricultural suitability. Journal of Biogeography 35: 1337-1348.

Loyola RD, Nabout JC, Trindade-Filho, Joaquim Lemes P, Urbina-Cardona JN, Dobrovolski R, Sagnoli MD \& Diniz-filho JAF (2012) Climate change might drive species into reserves: a case study of the American bullfrog in the Atlantic Forest Biodiversity Hotspot. Alytes 29: 61-74.

Loyola R (2014) Brazil cannot risk its environmental leadership. Diversity and Distributions 20: 1365 1367.

Loyola R, Machado N, Vila-Nova DA, Martins E \& Martinelli G (2014a) Áreas prioritárias para conservação e uso sustentável da flora brasileira ameaçada de extinção. Andrea Jakobsson estúdio: Instituto de Pesquisas Jardim Botânico do Rio de Janeiro, Rio de Janeiro. 80p.

Loyola RD, Lemes P, Brum FT, Provete DB \& Duarte LDS (2014b) Clade-specific consequences of climate change to amphibians in Atlantic Forest protected areas. Ecography 37: 65-72.

Loyola R \& Machado N (2015a) Áreas prioritárias para a conservação da flora ameaçada de extinção da Serra do Espinhaço Meridional. In: Plano de ação nacional para a conservação da flora ameaçada de extinção da serra do espinhaço meridional. Andrea Jakobsson estúdio: Instituto de Pesquisas Jardim Botânico do Rio de Janeiro, Rio de Janeiro. Pp 49-76.

Loyola R, Machado N \& Vila-Nova DA (2015b) Prioridades espaciais para a conservação da flora ameaçada de extinção de Grão Mogol - Francisco Sá. In: Plano de ação nacional para a conservação da flora ameaçada de extinção de Grão Mogol Francisco Sá. Andrea Jakobsson estúdio: Instituto de Pesquisas Jardim Botânico do Rio de Janeiro, Rio de Janeiro. Pp 47-60.

Loyola R, Machado N, Ribeiro BR, Martins E \& Martinelli G (2018) Áreas prioritárias para conservação da flora endêmica do estado do Rio de Janeiro. Graficci, Rio de Janeiro. 60p.

Martinelli G \& Moraes MÁ (2013) Livro vermelho da flora do Brasil. Instituto de Pesquisas Jardim Botânico do Rio de Janeiro, Rio de Janeiro. 1100p.

Martinelli G, Messina T \& Filho LS (2014) Livro Vermelho da Flora do Brasil: plantas raras do cerrado. Andrea Jakobsson estúdio, Instituto de Pesquisas Jardim Botânico do Rio de Janeiro, Rio de Janeiro. 320p.

Martinelli G, Martins E, Moraes M, Loyola R \& Amaro R (2018) Livro Vermelho da Flora Endêmica do estado do Rio de Janeiro. Andrea Jakobsson estúdio, Rio de Janeiro. 456p.

Martins E, Fernandes FM, Maurenza D, Pougy N, Loyola R \& Martinelli G (2014) Plano de Ação Nacional para a Conservação do Faveiro-de-wilson (Dimorphandra wilsonii Rizzini). Andrea Jakobsson estúdio, Instituto de Pesquisas Jardim Botânico, Rio de Janeiro. 52p.

Martins E, Loyola R \& Martinelli G (2017) Challenges and perspectives for achieving the global strategy for plant conservation targets in Brazil. Annals of the Missouri Botanical Garden 102: 347-356.

MMA (2000) Sistema Nacional de Unidades de Conservação. Available at $<$ http://www.mma.gov. br/areas-protegidas/sistema-nac $>$. Access on 09 December 2017.

MMA (2014) Portaria $n^{\circ} 443$, de 17 de dezembro de 2014. Available at <http://www.mma.gov.br/ biodiversidade/especies-ameacadas-de-extincao/ atualizacao-das-listas-de-especies-ameacadas $>$. Access on 09 December 2017.

MMA (2018) Cadastro Nacional de Unidades de Conservação. Available at <http://www.mma.gov. br/areas-protegidas/cadastro-nacional-de-ucs/ dados-consolidados $>$. Access on 09 December 2017.

Muñoz-Rodríguez P, Draper Munt D \& Moreno Saiz JC (2016) Global strategy for plant conservation: inadequate in situ conservation of threatened flora in Spain. Israel Journal of Plant Sciences 63: 1-12.

Nori J, Urbina-Cardona JN, Loyola RD, Lescano JN \& Leynaud GC (2011) Climate change and american bullfrog invasion: what could we expect in South America? PLoS ONE 6: e25718.

Oliveira U, Soares-Filho BS, Paglia AP, Brescovit AD, Carvalho CJB, Silva DP \& Santos AJ (2017) Biodiversity conservation gaps in the Brazilian protected areas. Scientific Reports 7: 9141.

Oliver TH, Smithers RJ, Beale CM \& Watts K (2016) Are existing biodiversity conservation strategies 
appropriate in a changing climate? Biological Conservation 193: 17-26.

Pacheco AA, Neves ACO \& Fernandes GW (2018) Uneven conservation efforts compromise Brazil to meet the Target 11 of Convention on Biological Diversity. Perspectives in Ecology and Conservation 16: 43-48.

Pebesma EJ \& Bivand RS (2005) Classes and methods for spatial data in R. R News 5 (2). Available at $<$ https://cran.r-project.org/doc/Rnews/>. Access on 09 December 2017.

Pougy N, Verdi M, Martins E, Loyola R \& Martinelli G (2015a) Plano de Ação Nacional para a conservação da flora ameaçada de extinção da região de Grão Mogol-Francisco Sá. Andrea Jakobsson estúdio, Instituto de Pesquisas Jardim Botânico do Rio de Janeiro, Rio de Janeiro. 44p.

Pougy N, Verdi M, Martins E, Loyola R \& Martinelli G (2015b) Plano de Ação Nacional para a conservação da flora ameaçada de extinção da Serra do Espinhaço Meridional. Andrea Jakobsson estúdio, Instituto de Pesquisas Jardim Botânico do Rio de Janeiro, Rio de Janeiro. 100p.

Pougy N, Martins E, Verdi M, Fernandez E, Loyola R, Filho TBS \& Martinelli G (2018) Plano de ação nacional para a conservação da flora endêmica ameaçada de extinção do estado do Rio de Janeiro. Secretaria de Estado do Ambiente (SEA), Andrea Jakobsson estúdio, Rio de Janeiro. 80p.

Pressey RL, Visconti P \& Ferraro PJ (2015) Making parks make a difference: poor alignment of policy, planning and management with protectedarea impact, and ways forward. Philosophical transactions of the Royal Society B. Biological Sciences 370: 20140280.
Schulman L, Toivonen T \& Ruokolainen K (2007) Analysing botanical collecting effort in Amazonia and correcting for it in species range estimation. Journal of Biogeography 34: 1388-1399.

Sharrock S, Oldfield S \& Wilson O (2014) Plant conservation report 2014: a review of progress in implementation of the Global Strategy for Plant Conservation 2011-2020. Technical series (Technical). Secretariat of the Convention on Biological Diversity, Montréal, and Botanic Gardens Conservation International, Richmond. 56p.

Soares-Filho B, Moutinho P, Nepstad D, Anderson A, Rodrigues H, Garcia R \& Maretti C (2010) Role of Brazilian Amazon protected areas in climate change mitigation. Proceedings of the National Academy of Sciences of the United States of America 107: 10821-10826.

Sobral M \& Stehmann JR (2009) An analysis of new angiosperm species discoveries in Brazil (19902006). Taxon 58: 227-232.

Sousa-Baena MS, Garcia LC \& Peterson AT (2014) Completeness of digital accessible knowledge of the plants of Brazil and priorities for survey and inventory. Diversity and Distributions 20: 369-381.

Strassburg BBN, Brooks T, Feltran-Barbieri R, Iribarrem A, Crouzeilles R, Loyola R, Latawiec AE, Filho FJBO, Scaramuzza CAM, Scarano FR, SoaresFilho B \& Balmford A (2017) Moment of truth for the Cerrado hotspot. Nature Ecology \& Evolution 4: 1-0099.

Vieira RRS, Ribeiro BR, Resende FM, Brum FT, Machado N, Sales LP \& Loyola R (2018) Compliance to Brazil's Forest Code will not protect biodiversity and ecosystem services. Diversity and Distributions 24: 434-438. 